\title{
An Estimation Method for Distribution System Load with Photovoltaic Power Generation based on ICA
}

\author{
Takayoshi YamadaＳtudent Member（Osaka Prefecture University, yamada07@eis.osakafu-u.ac.jp) \\ Atsushi Ishigame Senior Member (Osaka Prefecture University, ishigame@eis.osakafu-u.ac.jp) \\ Takamu Genji Member (Kansai Electric Power Co., Inc, genji.takamu@c4.kepco.co.jp)
}

Keywords: dispersed generation, photovoltaic power generation, independent component analysis, state estimation

A large number of Dispersed Generations (DGs) are expected to be installed in distribution systems. It is difficult to estimate the total power of DGs connected to a load-side system at a metering spot of supply-side system because at the metering spot only a sum of the active-power from various loads and DGs can be measured. Therefore the state estimation is important problem for stable and reliable system operation.

In this paper, we propose an estimation method for unknown DGoutputs connected to a distribution system. The method enables to estimate DG-outputs by analyzing a power flow data measured at one spot using independent component analysis (ICA). The estimation by ICA needs the same number of observations as estimations. However the observation spot is extremely limited in existing distribution system. So we propose an estimation method which enables to estimate DG-outputs and load-changes from only an observation by using known information of load power.

The outline of the proposed method is as follows. The value of the photovoltaics output $\left(P_{d q}\right)$ which is interconnected to a power distribution system, and electric load power $\left(P_{\text {load }}\right)$ is presumed in the unit of a daily variation curve, respectively. In the presuming method, ICA is applied by making the electric power measurement data (the active power $P_{\text {total }}$ and reactive power $Q_{\text {total }}$ ) in a power line into an observation signal, and $P_{d g}$ and $P_{\text {load }}$ are presumed.

The following inventive approach which utilized given information is performed in the application, and improvement in presumed accuracy is aimed at.

(1) Divide into the data section which applies ICA. In the section, the temporal response of power factor $(p f)$ of the power flow which can be found from $P_{\text {total }}$ and $Q_{\text {total }}$ is small. The partial presumption of $P_{d g}$ and $P_{\text {load }}$ is carried out for every divided section.

(2) The section where the change of $p f$ is large is not performed presumption, but is dealt with as the data lack section.

(3) The whole daily variation curve of $P_{d g}$ and $P_{\text {load }}$ is obtained by composition of the presumed result for every division section (that is the presumed curve of $P_{d g}$ ), and the lack section is presumed by interpolation.

(4) Interpolation using sine function to which fitting of the daily variation curve of insolation intensity for fine weather is carried out to the above-mentioned synthetic curve. The obtained interpolation sin curve turns into presumed whole $P_{d g}$ curve.

(5) The presumed result of $P_{\text {load }}$ is obtained by deducting the estimate value of $P_{d q}$ from observational data.

The numeric simulation is performed by the power distribution system model shown in Fig. 1. By the proposition 1, the presumed waveform of the whole PV output is compounded using the presumed data of the clipping section. By the proposition 2, the given information on an amount of insolation is used for the result of method 1 , and fitting of a sine wave form is carried out to it at the whole PV presumption waveform. The numeric simulation result of having set the ratio of the load-peak value to 1 to 1 is shown in Fig. 2 about PV output and the load curve at the time of fine weather. Figure 2 shows that PV output and the load curve have dissociated good with the proposed technique. As quantitative evaluation to whole form, the correlation coefficient of a true value waveform and a presumed waveform was calculated. The results when the ratio of the load-peak value of PV output and load is changed are shown in Table 1.

When the correlation coefficient of the proposition 1 and the proposition 2 is compared, it turns out that the proposition 2 becames a larger value than proposition 1 , and it can give a good result.

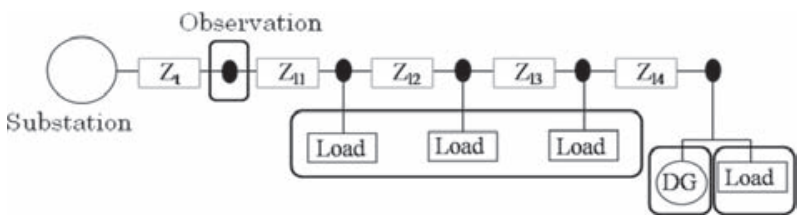

Fig. 1. Examination system

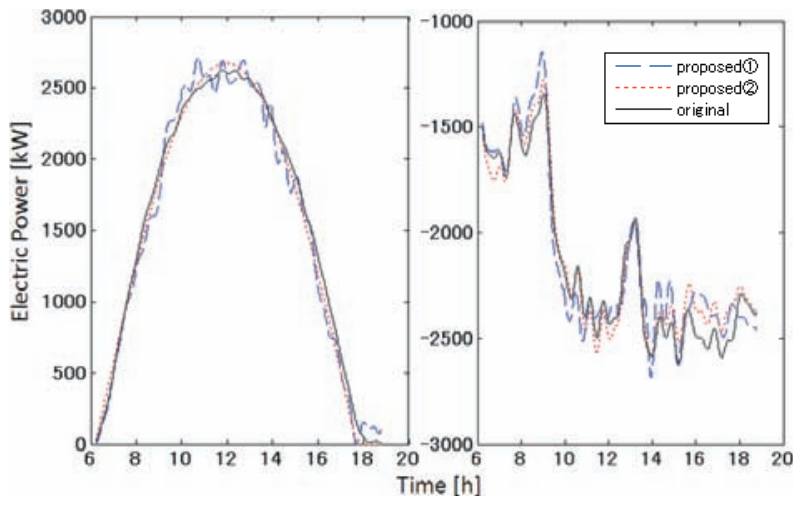

(PV : LOAD=1 : 1 Left : PV, Right : LOAD)

Fig. 2. Estimation result

Table 1. Correlation coefficient

\begin{tabular}{|c|c|c|c|}
\hline \multirow{2}{*}{ Object } & \multirow{2}{*}{ PV:LOAD } & \multicolumn{2}{|c|}{ Correlation Coefficient } \\
\cline { 3 - 4 } & $\begin{array}{c}\text { Proposed } \\
\text { method(1) }\end{array}$ & $\begin{array}{c}\text { Proposed } \\
\text { method(2) }\end{array}$ \\
\hline \multirow{3}{*}{ PV } & $1: 1$ & 0.9946 & 0.9976 \\
\cline { 2 - 4 } & $0.8: 1$ & 0.9914 & 0.9976 \\
\cline { 2 - 4 } & $0.6: 1$ & 0.9841 & 0.9972 \\
\hline \multirow{3}{*}{ LOAD } & $1: 1$ & 0.9696 & 0.9849 \\
\cline { 2 - 4 } & $0.8: 1$ & 0.9700 & 0.9888 \\
\cline { 2 - 4 } & $0.6: 1$ & 0.9703 & 0.9901 \\
\hline
\end{tabular}




\title{
先験情報を活用したICA による系統連系太陽光発電の出力推定手法
}

\author{
学生員 山田 貴義* 上級会員 石亀 篤司* 正 員 元治 崇**
}

\section{An Estimation Method for Distribution System Load with Photovoltaic Power Generation based on ICA}

Takayoshi Yamada*, Student Member, Atsushi Ishigame*, Senior Member, Takamu Genji**, Member

(2010年6月 7 日受付, 2010 年 12 月 9 日再受付)

\begin{abstract}
A large number of Dispersed Generations (DGs) are expected to be installed in distribution systems. Therefore the state estimation is important problem for stable and reliable system operation. However, it is difficult to estimate the total power of DGs connected to a load-side system from a metering spot on the distribution line because at the metering spot only a sum of the active-power from various loads and DGs can be measured. In this paper, we propose an estimation method for unknown DG-outputs connected to a distribution system. This method enables to estimate DG-outputs by analyzing a power flow data measured at one spot using independent component analysis (ICA). The estimation by ICA needs the same number of observations as estimations. However the observation spot is extremely limited in existing distribution system. So we propose an estimation method which enables to estimate DG-outputs and load-changes from only an observation by using known information of load power and a priori knowledge of insolation.
\end{abstract}

キーワード：分散型電源，太陽光発電，独立成分分析，状態推定

Keywords: dispersed generation, photovoltaic power generation, independent component analysis, state estimation

\section{1. はじめに}

低炭素社会の実現へ向けて分散型電源（DG：Dispersed Generation）が注目を浴び，“低炭素社会づくり行動計画” の具体策の 1 つとして太陽光発電 (PV : Photovoltaic power generation) の導入量を 2020 年に現状の 10 倍, 2030 年に 40 倍にする目標が掲げられている。よって, 今後 PV の配 電系統への連系が急速に増大して行くものと予想される。 配電系統への DG 導入量がふえると逆潮流や発電出力の不 確定性の影響により, 系統運用や設備計画の面で種々の問題 が出てくる ${ }^{(1) \sim(3)}$ 。それらの問題に適切に対応するには, 系 統内での状態推定が重要になることから, 連系 DG の出力推 定や系統状態の推定に関する研究が種々行われている ${ }^{(4) \sim(9)}$ 。 大容量の DGに関しては, 連系箇所数が少ないことから, 個別にセンサを設置して状態を把握することができる。一

\footnotetext{
$*$ 大阪府立大学 大学院工学研究科

于 599-8531＼cjkstart堺市中区学園町 1-1

Graduate School of Engineering, Osaka Prefecture University

1-1, Gakuen-cho, Naka-ku, Sakai 599-8531, Japan

** 関西電力 (株) 電力技術研究所

干 661-0974 尼崎市若王寺 3-11-20

Kansai Electric Power Co., Inc.

11-20, 3-chome, Nakouji, Amagasaki 661-0974, Japan
}

方, PVについては, 小容量の装置が多数連系されることか ら，個別にセンサを設置するような方法をとることは困難 であり，できるだけ少ないセンサで精度よく推定する方法 が求められている。

このような課題に対し, 前記文献(4) (6)では, DG の連系 がない状態や負荷設備情報を予め把握しておき, それから の乘離情報を活用して DG 出力を推定するなどの方法がと られている。このような方法は, 予めの情報把握に多大の 労力を要すること, 系統構成や接続負荷の変更に対応する ための情報管理の負担が生じると言った課題が考えられる。 そこで筆者らは，少ないセンサで，かつ，上述のような負 担もなく PV 出力を推定する方法を検討した。

本論文では，信号処理手法の 1 つである独立成分分析 (ICA：Independent Component Analysis）を用いて, 配電 系統での限られた測定データから配電系統に連系された PV の出力を推定する新たな手法を提案し, その手法の有効性 を検証する。まず，本論文で用いる ICA について説明し， 配電系統の負荷推定へICA を適用するに際しての課題を挙 げる。次に, ICAによる定式化を示し，その原理を検証す る。また，推定評価を容易に行うため, 推定対象としてい る PV 出力と負荷電力変化を解析し, 両者の再現に必要な 最低周波数条件を考察する。最後に，モデル配電系統にお 
いて，工場地域配電系統の負荷曲線と PV 出力曲線の実測 データを用いて数值シミュレーションを行い, 提案手法の 有効性を評価する。なお，ICAのアルゴリズムとしては高 速アルゴリズムである fastICA を用いている。

\section{2. 配電系統負荷推定の課題}

〈2・1〉配電系統負荷の推定 多くの DG が連系され た配電系統を適切に運用するためには, 負荷電力変化と DG の出力実態を把握する必要がある。現状では，そのための 手段としては DG 連系点で個別に電力を測定し, 通信線で そのデータを伝送するなどの計測手段をとっている。この 方法では個々のDG に対して通信線が必要となることから， DG の台数が増加した場合などにはコスト面で対応できな い。特に，PVのように小容量の DG が多数連系された場 合には，そのような方法はほぼ不可能になる。このような 系統状況においても，少なくとも負荷電力変化と DG の出 力変化を分離して把握することが望まれている。

$\langle\mathbf{2} \cdot \mathbf{2}\rangle$ 独立成分分析 観測信号 $\mathbf{x}(t)=\left[x_{1}(t), x_{2}(t), \ldots\right.$, $\left.x_{\mathrm{m}}(t)\right]^{T}$ は, 元信号 $\mathbf{s}(t)=\left[s_{1}(t), s_{2}(t), \ldots, s_{\mathrm{n}}(t)\right]^{T}$ の瞬時混合 で得られるとし，(1)式のモデルを考える。

$$
\mathbf{x}(t)=\mathbf{A s}(t)
$$

ただし A は混合過程を表す混合行列である。

ここで基本的な ICA では $m=n$ であり, 混合行列 $\mathbf{A}$ がフ ルランクであるという条件を必要とする。この条件によっ て混合行列 $\mathbf{A}$ は正則行列となり, 逆行列 $\mathbf{A}^{-1}$ をもつことに なる。

ICA は混合行列 $\mathbf{A}$ に関する情報を用いることなく，(2) 式のように復元行列 $\mathbf{W}$ を求めることを目的としている。

$$
\mathbf{y}(t)=\mathbf{W} \mathbf{x}(t)
$$

このとき元信号 $\mathbf{s}(t)$ は統計的に独立であると仮定し，復 元信号 $\mathbf{y}(t)$ の独立性を高めるように復元行列 $\mathbf{W}$ を選択す ることで，観測信号 $\mathbf{x}(t)$ のみから元信号 $\mathbf{s}(t)$ の推定を行う。

このとき復元行列 $\mathbf{W}$ が混合行列 $\mathbf{A}$ の逆行列として, つ まり WA = I (単位行列) のように求めることができれば, 復元信号 $\mathbf{y}(t)$ は元信号 $\mathbf{s}(t)$ に完全に一致する。しかし，元 信号の大きさと順序に関しては信号の独立性に影響を与え ないことから，これらは独立性の指標のみでは決定するこ とができない。ICA は $\mathbf{y}(t)$ の独立性を高めるようにWを 決定する手法であり，独立性を評価する指標とその最適化 手法によって様々な手法が提案されている(10)。

これまで ICA を用いて DG の数と同数の線路潮流観測 データからそれぞれの DG の出力を推定する手法が提案さ れている ${ }^{(11)}$ 。しかし，その手法では，1 分岐線あたり 1 つ のノードに接続された DG の出力変化を推定する手法であ り，DGの台数相当の観測デー夕数を必要とし，また，負 荷の変動を一定とした条件でなければ DG の出力変化を推 定することはできなかった。ICA は観測信号の数と信号源
の数が同じという条件をもつため，1箇所の観測潮流だけ では DG の出力変化と負荷電力の変化を推定することはで きない。また，実際の配電系統において多数の観測点は期 待できない。よって, ICA 適用に際してはそれらの課題を 解決する必要がある。

\section{3. 手法の定式化}

DG として多数の PV が系統に接続されたと考え, Fig. 1 に示す簡単な配電系統モデルを想定する。PVは日射によっ て出力が決まることから，1配電系統の区域内に連系された 多数の PV はまとめて，1 つの DG として扱うことができる と考えられる。また，Load は負荷である。よって，PVの 出力変化と負荷変化はそれぞれ独立に変化しており, ICA における主要な独立成分と見なすことができる。このよう なモデルの下, “配電系統に連系した PV の出力を, 配電線 路に設置される限られたセンサでの測定データから簡便に 推定する”手法について検討する。具体的には，配電線路 の 1 点にセンサを設置し, 線路潮流に関連するデー夕を適 当な時間間隔で測定し，観測点での日負荷曲線を取得する。 その観測データから PV 出力と負荷電力の变化を推定する。

観測点で計測された有効電力は，配電損失を無視すれば PV の出力と負荷電力の合算值であり，(3) 式で与えられる。 ただし，無効電力に関してはPVの無効電力を 0 ，すなわ ち力率 1 で運転するように制御されているという仮定を置 く。よって，無効電力の関係は (4) 式で表わされる。上述 の PV 運転状態は，系統電圧が過昇にならければ維持され ており，ほとんどの時間帯において上記仮定は適用可能で あると考えられる。

$$
\begin{aligned}
& P_{\text {total }}(t)=P_{\text {load }}(t)-P_{d g}(t) \\
& Q_{\text {total }}(t)=Q_{\text {load }}(t) \\
& P_{\text {total }}(t), Q_{\text {total }}(t) \text { : 観測点での有効電力, 無効電力 } \\
& P_{\text {load }}(t), Q_{\text {load }}(t) \text { : 負荷電力の有効電力, 無効電力 } \\
& P_{d g}(t): \mathrm{PV} \text { の有効電力 }
\end{aligned}
$$

この情報のみを用いて PV の出力と負荷電力の変化を推定 するために，本論文では ICA を用いる。

ここで目的は $P_{d g}(t)$ と $P_{\text {load }}(t)$ を元信号 $\mathbf{s}(t)$ (独立成分) とみなし，これを推定することである。(3) 式では観測信号 $P_{\text {total }}(t)$ に対して $P_{d g}(t)$ と $P_{\text {load }}(t)$ は線形の関係にあり ICA を適用できる形となっている。一方，基本的な ICA の条件 として観測信号数 $(m)$ と信号源の数 $(n)$ は同じである必

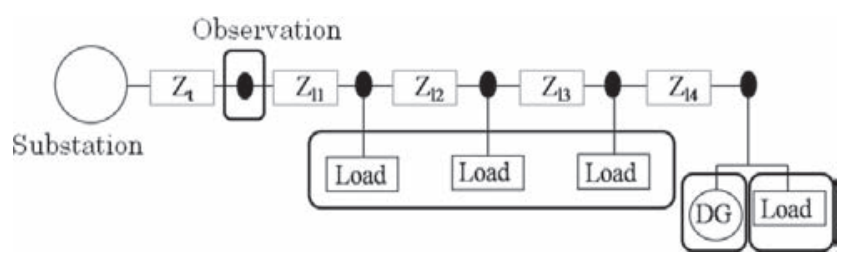

Fig. 1. Model system for examination. 
要があるが, $P_{\text {total }}(t)$ という 1 種類の情報だけでは前記条件 を満足しない。

そこで，(4) 式の関係を利用して観測点の無効電力潮流を もうひとつの情報として用いる。この場合, 元信号 $P_{\text {load }}(t)$ と観測信号 $Q_{\text {total }}(t)\left(Q_{\text {load }}(t)\right)$ の関係は, (5) 式のようになる。

$$
\begin{aligned}
& Q_{\text {load }}(t)=\sqrt{\frac{1}{r^{2}}-1} \cdot P_{\text {load }}(t) \\
& r: \text { 負荷の力率 }
\end{aligned}
$$

（5）式を (4) 式に代入し，(3) 式と合わせて行列表現すると， 推定すべき元信号と観測信号の関係は (6) 式のように定式 化できる。

$$
\left[\begin{array}{l}
P_{\text {total }}(t) \\
Q_{\text {total }}(t)
\end{array}\right]=\left[\begin{array}{cc}
1 & 1 \\
0 & \sqrt{\frac{1}{r^{2}}-1}
\end{array}\right] \cdot\left[\begin{array}{c}
-P_{d g}(t) \\
P_{\text {load }}(t)
\end{array}\right] \ldots
$$

ここで，(6) 式のように想定したモデルにICAを適用す る場合，混合行列は線形で時間的にも不変である必要があ る。すなわち, (6) 式の混合行列の 2 行 2 列目の要素に関 して, 負荷電力の有効電力と無効電力が常に一定力率の関 係を保っていることが必要である。配電系統負荷が全体と して一定力率であるという条件は一般的には成立困難であ るが，一方の推定対象としてPV を想定しているので，現 実的には以下のような条件が適用できると考えられる。

(1) 観測信号は，PV出力波形とその他をまとめた負荷電 力波形の 2 波形の合成とする。

(2) PV の出力は, 力率 $=1$ で運転されている。つまり, $Q_{d g}(t)=0$ である。

(3) PV が出力している時間帯の多くは, 負荷力率 $(\boldsymbol{r})$ は，時間的に変化せずほぼ一定值（1.0〜0.95）となっ ている実態である。

この条件ならば (6) 式の混合行列に関して前述の条件を 満足することから，このデータ区間に限定して ICA を適用 すればよい。力率が大きく変化する時間帯にも適用すると， 明らかに混合行列が時間不变にはならず，その弊害が表れ てしまうと考えられる。

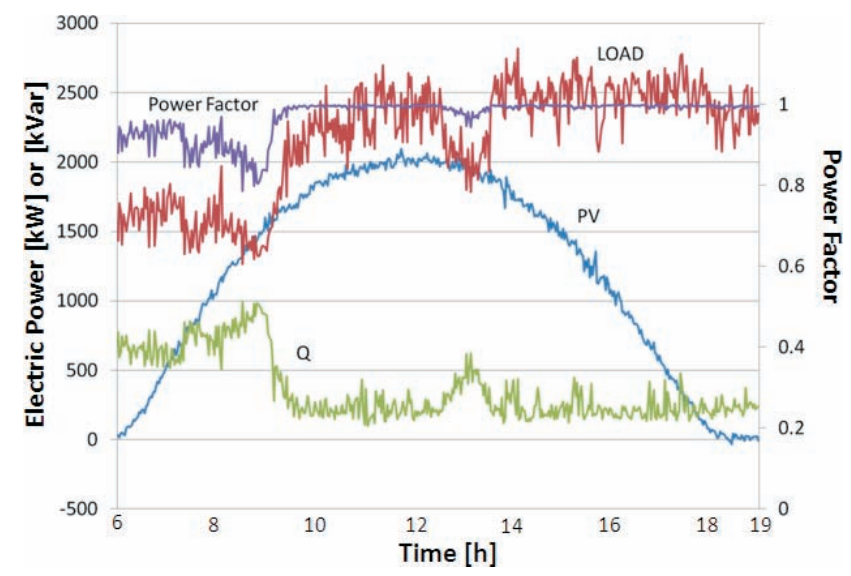

Fig. 2. $\mathrm{P}(\mathrm{PV} \& \mathrm{LOAD})-\mathrm{Q}-\mathrm{PF}-$ change curve.
Fig. 2 に，PV 出力と配電系統負荷の実測波形例を，時間 軸を重ねて示す。横軸は時間 $[\mathrm{h}]$, 縦軸は第 1 軸が $[\mathrm{kW}$ or $\mathrm{kVar}$, 第 2 軸が力率を表している。また, PV は PV の有 効電力, $\mathrm{LOAD}$ は負荷の有効電力, $\mathrm{Q}$ は負荷の無効電力, Power Factor は力率を各々表している。Fig. 2 から，上記 (1)（3)の条件設定は概ね妥当であることが分かる。

以上に述べた ICA モデルにおいて，測定した観測信号 $P_{\text {total }}(t), Q_{\text {total }}(t)$ に ICA を適用し, 元信号 $P_{d g}(t)$ と $P_{\text {load }}(t)$ の推定值を (2) 式に示す復元信号 $\mathbf{y}(t)$ として分離する。

\section{4. 原理の検証}

(6) 式に示した，元信号と観測信号の関係を Fig.1 の配電 系統モデルに設定して数值シミュレーションを行い, 前章 で述べた原理を検証する。負荷電力の変化は工場地域配電 系統の実測負荷曲線を, PV 出力は晴天時の出力実測曲線を 用い，線路末端にPV を接続すると仮定した。デー夕点数 は 24 時間あたり 864 点，すなわち 100 秒で 1 点とし，PV が出力している時間帯に相当する 453 点 (Fig. 2 の時間帯) を ICA 適用区間とする。

Fig. 3 に数值シミュレーション結果を示す。PV 出力の真 值を左上，推定值を右上，負荷曲線の真值を左下，推定值 を右下に表している。また，各図で横軸は時間 $[\mathrm{h}]$, 縦軸は 電力 $[\mathrm{kW}]$ である。なお，発電量を正，消費量を負で表現 している。

Fig. 2 と Fig. 3 を対照すると, 負荷力率の変化が小さい 時間帯では，大まかな形状に影響を与える成分は概ね分離 できていることが分かる。しかし，力率が大きく変動する 時間帯では, 負荷力率の変動 (一定でない成分) が PVの 推定波形に混入していることが分かる。また，力率のレべ ルが大きく異なる区間のデー夕を一括して処理しているこ とから，波形全体を見た分離精度も低下していることが分 かる。これらを(6) 式の条件下での ICA 計算による誤差と 考えると，これら誤差要因を排除するには，力率変動が大

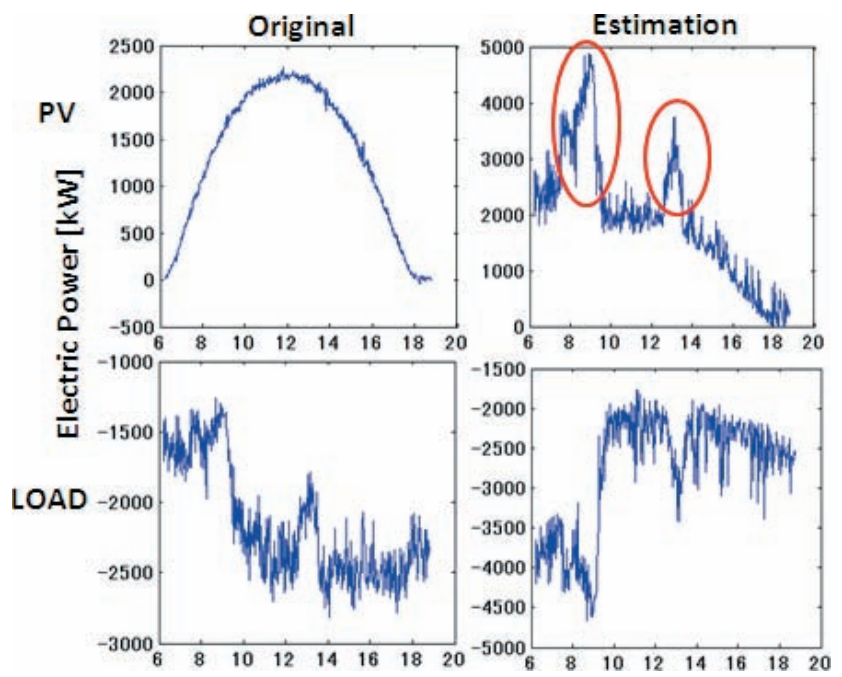

Fig. 3. Estimation result. 
きい部分や力率のレベルが大きく異なっている区間同士を 分けて処理する必要があると考えられる。そこで，ICA 計 算を適用して PV 出力波形全体を推定するため, 前処理と して $\langle 4 \cdot 1\rangle$ 節を，後処理として $\langle 4 \cdot 2\rangle$ 節を加える。

$\langle\mathbf{4} \cdot \mathbf{1}\rangle$ 混合行列モデルの条件を満たすデータ区間の分 類 Fig. 2 において有効電力・無効電力ともに変動してい るが, 力率のレベルがほぼ一定になっている区間がある。そ こで, Fig. 4 のように力率の変化様相に応じて時間帯を分類 する。図の(2)(4)区間は極めて一定性の高い時間帯になっ ている。(1)(3)の間は(2)(4)に比べて変動幅が大きくなって いる。また，(1)と(2)の間および(2)と(3)の間等では，力率レベ ルの大きな段差を生じている。

このような力率変化による波形推定への弊害を避けるた め，力率一定と見なせる区間を切り出してその区間ごとに ICA を適用する。つまり，(5) 式で記述される観測データ $P_{\text {total }}(t)$ と $Q_{\text {total }}(t)$ から観測デー夕の力率がほぼ一定となっ ている範囲を負荷力率 $r$ が一定の区間と見なし, ICA 適用 区間を決定する。

このようにして切り出した区間にICAを個別に適用し， 部分的に推定したデータを最後に合成して $P_{d g}(t)$ の推定值 とする。なお, Fig. 2 と同様に PV が出力している時間帯は 453 点を ICA 適用区間としている。

本論文では，ICA 適用にあたって，上述のような PV の 出力実態, $\mathrm{PV}$ 出力時間帯における負荷力率の実態を先験 （既知）情報として利用する。

$\langle\mathbf{4} \cdot \mathbf{2}\rangle$ 力率変動による誤差の修正 $\langle 4 \cdot 1\rangle$ 節のよう に，力率が一定と見なせる時間帯に分割しても，(1)(3)よう に区間内でさらに細かい力率変動がある場合，それによる 推定誤差を抑制する必要がある。そこで，そのような時間 帯をデータ欠落区間として取り扱う。データ欠落区間の補 間方法として，推定欠落区間のデータ点数分だけ前後の推 定デー夕を参照し，その参照デー夕を元にキュービック補 間を行うと言った方法が考えられるが，欠落の状況によっ ては適切な補間が出来なくなる場合がある。

一方, PV 出力波形に着目すると, Fig. 2 に示すような晴 天時の出力波形に対し, 天候によってはそれから崩れた種々

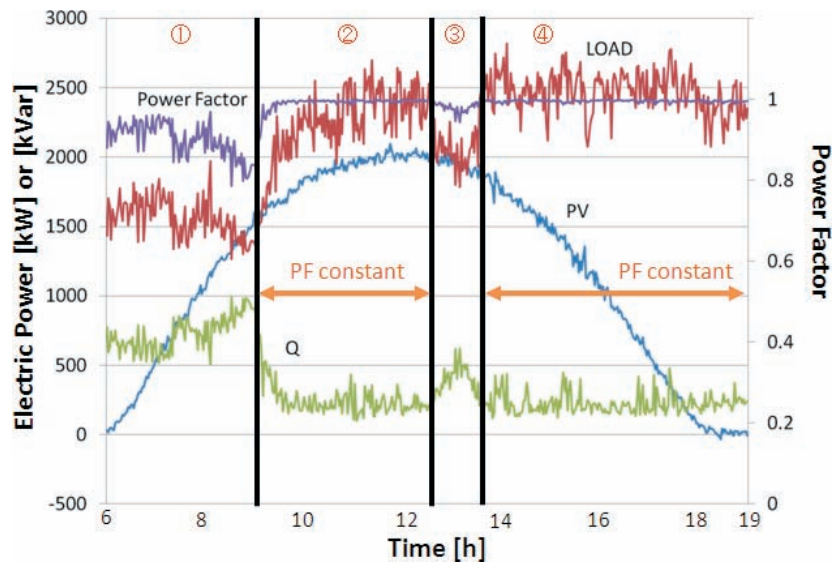

Fig. 4. Classification of time section to apply ICA.
の波形になる。実用的には雲の移動による細かい変動まで 捉える必要はなく，そのときの平均的な日射に対応した連 続波形を推定できればよいと考えられる。そこで，季節・ 緯度・パネル取り付け角度を固定して考えた場合の 1 日あ たりの日射波形が， $A \cdot \sin (t)$ になることを先験（既知）情 報として使用する。大気外全天日射量 $\mathrm{Q}$ が正弦波形で表わ されることが“斜面日射量について”の文献で報告されて いる ${ }^{(12)}$ 。この情報を利用すれば，欠落区間前後のデータに 左右されることなく $\mathrm{PV}$ 出力波形の任意の部分を補間でき る。また， $P_{d g}(t)$ の推定值に力率変動による誤差が重畳さ れた場合でも，それを排除できる。そこで，〈4·1〉節のよ うに区間分けしたデータを使って $P_{d g}(t)$ の全体波形を推定 した後，これに最もフィットするように最小二乗法を用い て $A \cdot \sin (t)$ の振幅 $A$ を決定し, これを $P_{d g}(t)$ の推定曲線 とするという補間法を採用する。この方法によれば，変動 量により影響を受けた推定值に引きずられて, 現在良好に 推定されている部分が真值から乘離してしまうことが予想 されるが，誤差率が最大の点の誤差は抑制することができ， 総合的には推定精度の向上になると考えられる。

\section{5. ローパスフィルタの要求性能}

原理の検証において，ICA が PV 出力波形の大まかな形 状を良好に分離出来ることは確認出来た。しかし，雲の変 動に加えて負荷力率の細かい変動が PV 出力の推定波形に 混入することから，推定性能の評価が困難となる。そこで, 観測デー夕の周波数成分をできるだけ雲の変動速度に近い 周波数まで落とすためには，高周波成分をフィル夕により 除去する必要がある。また，実用面においては，配電自動 化システムの区分開閉器内蔵センサで観測データを測定す る場合，確保できるサンプリング周期の細かさには限界が ある。これらの観点から, 推定対象とする PV 出力曲線 · 負荷曲線の再現に必要となる周波数構成を見極める必要が ある。

〈5・1〉 PV 出力波形の解析 晴天時の PV 出力波形を 解析し, 晴天時のきれいな波形を再現するために必要な周 波数条件を算出する。Fig. 5 に 24 時間を 1 周期とした PV 出力波形のスペクトルを示す。縦軸はパワー，横軸は $[\mathrm{Hz}]$

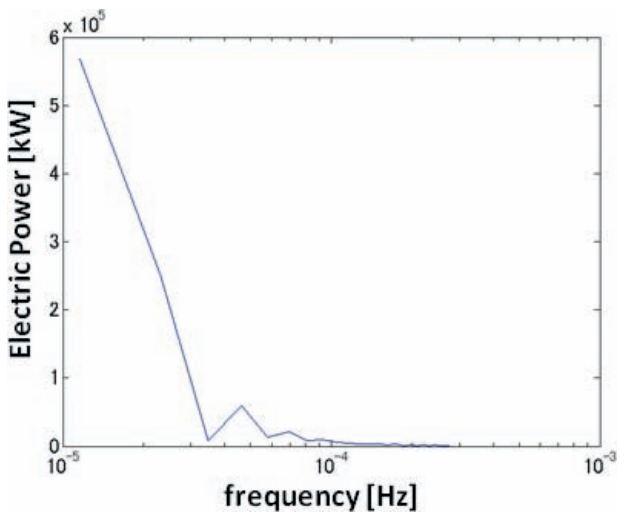

Fig. 5. Spectrum of PV curve. 
である。

このように晴天時の PV は低周波成分が大きく，0.0001 $[\mathrm{Hz}]$ より高い周波成分は 0 に近い值となり，直流成分に比 べて非常に小さくなっている。再現性を考慮すると，直流 成分のパワーの $0.5 \%$ 未満であれば十分許容出来ると考えら れる。その值は $0.00019676[\mathrm{~Hz}]$ であり，それを晴天時の PV を再現するための周波数条件とする。ただし，量天時 のように日射が細かい周期で変化しているような波形に対 しては，どの程度の細かさまでを把握するかによって，考 慮する周波数帯域は変える必要がある。

$\langle\mathbf{5} \cdot 2\rangle$ 負荷電力曲線の解析 負荷電力曲線を解析し, Fig. 3 で示したような細かい変動を含まない負荷電力曲線 を再現するために必要な周波数条件を算出する。つまり, Fig. 3 の負荷曲線で現れているような細かい変動はノイズ としてとらえることになるので, 電力変化の低周波成分の 特徴が把握出来ればよい。

Fig. 3 の負荷曲線の代わりに, 工場地域配電系統の皮相電 流デー夕例を解析して周波数条件を考察する。デー夕点数は 24 時間で 24 点である。Fig. 6 に 24 時間を 1 周期とした皮相 電流データのスペクトルを示す。縦軸はパワー, 横軸は [Hz] である。負荷についても低周波成分が大きく, $0.0001[\mathrm{~Hz}]$ よ り高い周波成分は 0 に近い值となり，直流成分に比べて非常 に小さくなっている。負荷の場合は $0.00008102[\mathrm{~Hz}]$ 以降で 直流成分のパワーの $0.5 \%$ 未満となっているが, 負荷が変動す る端点の再現性まで考慮して, 周波数条件を $0.00055556[\mathrm{~Hz}]$ とする。なお，上述の周波数条件は，1 時間ごとの測定を 24 時間行なった波形を分析した結果であるので，1 時間以 内に生じる細かい周期の変化はカットされた結果になって いる。したがって，そのような細かい変化までを把握する 場合には，考慮する周波数带域は変える必要がある。

〈5·3〉 ローパスフィルタの要求性能＼cjkstart本論文の ICA による波形推定システムで考慮すべき周波数条件は，上記 の 2 つの周波数の高い方までを考慮する必要があり，先の 結果から, 推定波形の再現に必要なローパスフィルタの要求 性能は“0.00055556 [Hz] 未満を通過させるフィル夕”であ れば良い。処理フローとしては，観測信号をローパスフィ

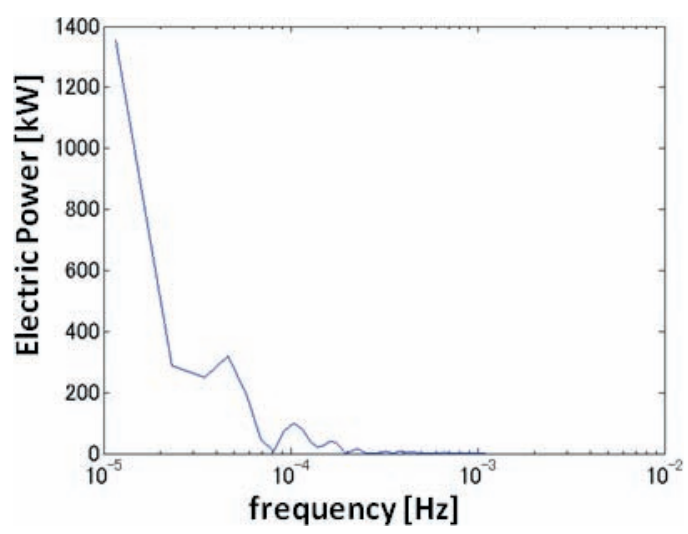

Fig. 6. Spectrum of apparent current curve.
ルタに通してから ICA を実施する。ローパスフィルタを通 す方法として，まず観測データをフーリエ変換して周波数 領域で表し，その周波数領域で $0.00055556[\mathrm{~Hz}]$ 以上の周 波数帯の值を全て 0 にする。そして, そのデータに対して 逆フーリエ変換を行い，時間領域に戻してフィル夕処理を 完了する。よって，処理過程の通過帯域において信号の減 衰や位相シフトは生じない。

\section{PV 出力と配電系統負荷の分離システム}

3 章で述べた ICA 適用モデルと 4 章で述べた力率変動区 間の補間法を組み合わせて，PV 出力と配電系統負荷を分 離・推定する実用的な処理アルゴリズムを提案する。提案 手法のフローチャートを Fig. 7 に示す。

実施手順としては，まず観測データにローパスフィル夕 でフィルタリングを行う。そして観測した力率変化を参考 に負荷の力率が一定とみなせる時間帯に分類して ICA 適用 区間の切り出しを行う。切り出した各区間に対して (6) 式 を想定して個別にICA 計算を行う。各切り出し区間の推定 データを用いて PV 出力全体の推定波形を合成する。この 方法を提案手法(1)とする。次に，(1)の結果に日射の先験（既 知）情報を用いて PV 推定波形全体に正弦波形のフィッティ ングを行う。この処理ステップを提案手法(2)とする。最後 に(3) 式から負荷の推定波形を算出して推定を完了する。

7. 数值シミュレーション

本論文で提案する手法の妥当性と推定精度を検証するた め, Fig. 7 のフローに基づき, Fig. 1 の配電系統モデルで数

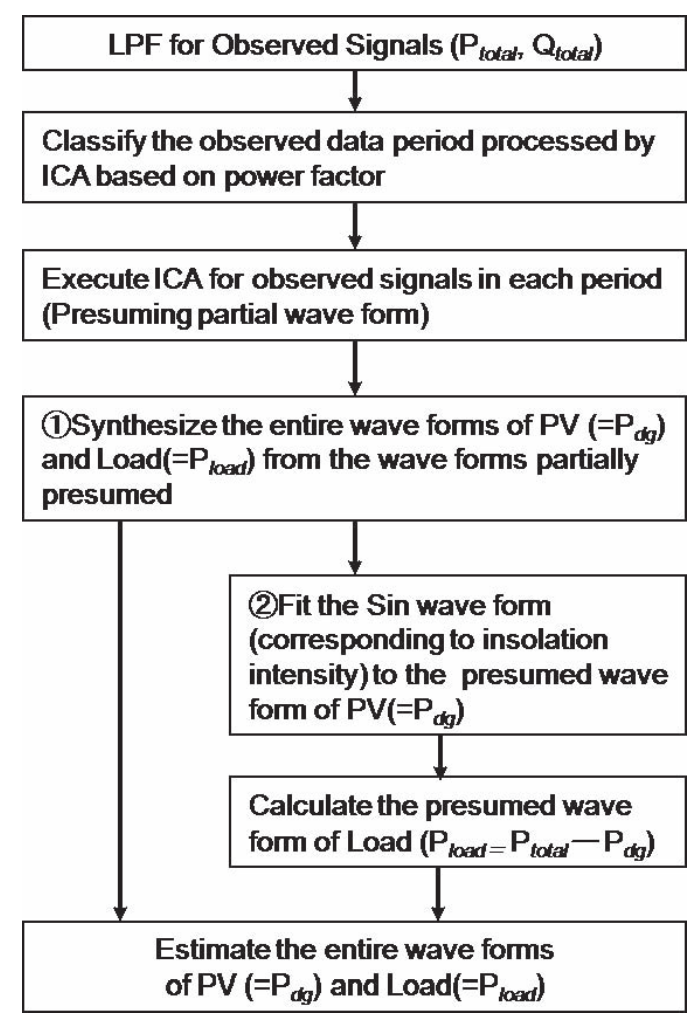

Fig. 7. Flow chart for proposed method (1) and (2). 


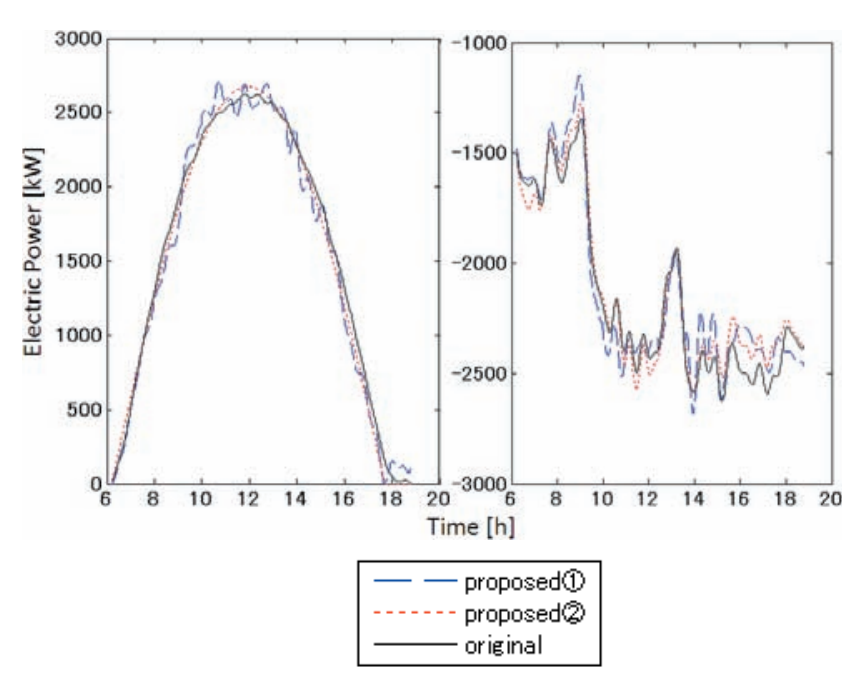

(PV : LOAD=1 : 1 Left : PV, Right : LOAD)

Fig. 8. Estimation result.

值シミュレーションを行った。負荷電力変化は工場地域配 電線の負荷曲線を, PV の出力は晴天時の出力曲線を用い た。デー夕点数は 8640 [sample] のデー夕を用いた。シミュ レーションではサンプリングを 24 時間あたり 864 点, す なわち 100 秒で 1 点とし, PV が出力している時間带であ る 453 点を ICA 適用区間としている。

$\langle\mathbf{7} \cdot \mathbf{1}\rangle$ 全体形状推定に関する検証 提案手法の基本 的な機能である PV 出力波形の推定性能を，雲による日射 の変動等を含まない判り易い形で把握するため, 晴天時の $\mathrm{PV}$ 出力と負荷の変化曲線に関し, 電力ピーク值の比を $1: 1$ とした場合の数值シミュレーションを行った。その結果を Fig. 8 に示す。実線が真值を，破線が提案手法(1) ，点線が 提案手法(2)をそれぞれ示している。ここで，提案手法(2に 扣いて正弦波曲線でフィッティングを行う領域は，推定值 に拉いて夕方付近で出力が 0 となる時間までとしている。

Fig. 8 から提案手法(1によって PV 出力と負荷曲線が良 好に分離されて抢り, $\mathrm{PV}$ 出力波形の全体形状は真值に近 い近似正弦波形として推定できている。このことから，力 率が同じレべルの区間に分割し各々の区間に対して ICAを 適用することで, Fig. 3 の推定結果に示すような力率変化 の影響と考えられる正弦波形からのゆがみや大きな突起を 生じるといった問題が回避できていることがわかる。よっ て, 力率のレベル変化が少ない区間に分割して ICA を適用 するという，本論文の提案は妥当であると考えられる。

また，正午頃に最も力率の変動を受けているが，提案手 法(2である正弦波フィッティングにより巨視的にも総誤差 量が少ないデー夕になっている。

形状推定に対する定量的評価として, 真值波形と推定波 形の相関係数を求めた。PV 出力と負荷の電力ピーク值の 比を変えたときの結果を Table 1 に示す。提案手法(1)と提 案手法(2)相関係数を比較すると，提案手法(2の方が大き く，良好に推定出来ていることが分かる。また，どちらの
Table 1. Correlation coefficient.

\begin{tabular}{|c|c|c|c|}
\hline \multirow{2}{*}{ Object } & \multirow{2}{*}{ PV:LOAD } & \multicolumn{2}{|c|}{ Correlation Coefficient } \\
\cline { 3 - 4 } & $\begin{array}{c}\text { Proposed } \\
\text { method(1) }\end{array}$ & $\begin{array}{c}\text { Proposed } \\
\text { method(2) }\end{array}$ \\
\hline \multirow{3}{*}{ PV } & $1: 1$ & 0.9946 & 0.9976 \\
\cline { 2 - 4 } & $0.8: 1$ & 0.9914 & 0.9976 \\
\cline { 2 - 4 } & $0.6: 1$ & 0.9841 & 0.9972 \\
\hline \multirow{3}{*}{ LOAD } & $1: 1$ & 0.9696 & 0.9849 \\
\cline { 2 - 4 } & $0.8: 1$ & 0.9700 & 0.9888 \\
\cline { 2 - 4 } & $0.6: 1$ & 0.9703 & 0.9901 \\
\hline
\end{tabular}

Table 2. Error evaluation for proposed method (1) and (2).

\begin{tabular}{|c|c|c|c|c|c|c|c|}
\hline \multirow{2}{*}{ method } & error & \multicolumn{5}{|c|}{ PV:LOAD } \\
\cline { 2 - 7 } & $1.0: 1.0$ & $0.8: 1.0$ & $0.6: 1.0$ & $0.4: 1.0$ & $0.2: 1.0$ & $0.1: 1.0$ \\
\hline \multirow{3}{*}{$\begin{array}{c}\text { Proposed } \\
\text { method(1) }\end{array}$} & $\begin{array}{c}\text { Maximum error } \\
{[\mathrm{kW}]}\end{array}$ & 38028 & 37260 & 38204 & 42109 & 48383 & 52159 \\
\cline { 2 - 7 } & $\begin{array}{c}\text { Rate of max error } \\
{[\%]}\end{array}$ & 103.49 & 107.10 & 113.31 & 125.77 & 163.65 & 239.57 \\
\hline \multirow{2}{*}{$\begin{array}{c}\text { Proposed } \\
\text { method(2) }\end{array}$} & $\begin{array}{c}\text { Total error } \\
{[\mathrm{kW}]}\end{array}$ & 27572 & 21862 & 20864 & 23688 & 31224 & 36445 \\
\cline { 2 - 8 } & $\begin{array}{c}\text { Maximum error } \\
{[\mathrm{kW}]}\end{array}$ & 157.59 & 126.13 & 104.27 & 118.72 & 138.85 & 149.44 \\
\cline { 2 - 7 } & $\begin{array}{c}\text { Rate of max error } \\
{[\%]}\end{array}$ & 101.58 & 102.90 & 105.35 & 110.17 & 125.40 & 156.18 \\
\hline
\end{tabular}

提案手法も PV の割合が小さくなるにつれて PV の相関係 数が小さくなっていることが確認される。これは, 力率の 変動状況としては同じであっても, 電力比が変わることに よって無効電力の変動量には相違が生じるため, この相違 が PVの出力推定值の精度に微視的な影響を及ぼしている 可能性があると考えられる。

\section{〈7・2〉 電カピーク比と推定精度の関係に関する検証}

前節の検討結果から, 力率変化が巨視的に見て一定であっ ても，その変化は無効電力変動につながっており，無効電 力の変動幅が PV 出力推定の微視的精度に影響することが 想定される。一方, 提案手法の適用に際しては, 種々の系 統条件に対して適用できることが必要である。具体的には, 任意の PV と負荷の電力ピーク比に対しても一定の推定精 度を達成できることが必要である。そこで, PV と負荷の電 力比をパラメータとして系統条件を変化させてシミュレー ションを行い，提案手法の有効性を微視的誤差の観点から 評価した。波形全体の誤差総量, 最大誤差点の誤差ならび に最大值の䛊差率を Table 2 に示す。また, 誤差率が最悪 である PV と負荷のピーク電力比 $0.1: 1$ における PV 出力 推定波形を Fig. 9 に示す。

提案手法(1)適用したときの誤差に関しては, Table 2 よ り PV の比率が小さくなるにつれて誤差率は悪くなってい るが, 誤差の絶対值抒よび誤差総量は誤差率に比べて変化 が少ないことが分かる。一方, Fig. 8 と Fig. 9 に扔いて, 提 案手法(1による負荷曲線の分離結果同士を比較すると両者 の間には大きな差は見られない。このことから, PV の出力 および負荷それぞれの有効電力の推定誤差は, ICA アルゴ リズムにおける混合行列の必要条件に対する違反 (力率变 


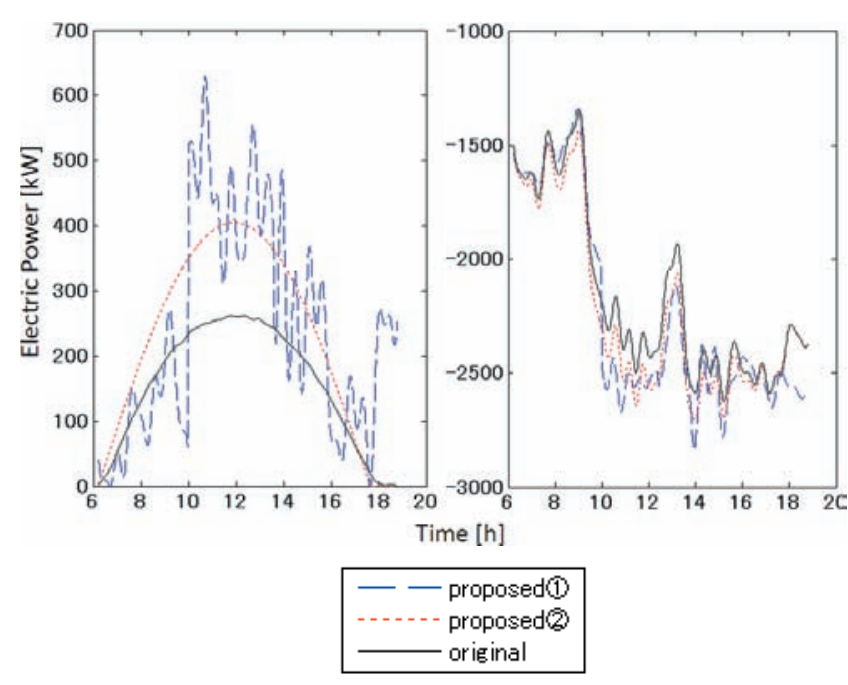

(PV : LOAD $=0.1: 1 \quad$ Left $:$ PV, Right : LOAD)

Fig. 9. Estimation result.

動）によるものであるが，負荷力率の変動よりも無効電力 そのものの変動の大きさによって影響を受けているものと 考えられる。つまり, 混合行列の必要条件に対する違反に 相当する無効電力の変動が, 復元行列の演算過程で PV 出 力の有効電力に移行しているものと推察される。また, 手 法の適用に際して許容できる誤差率を $5 \%$ とすると，提案 手法(1の適用範囲は, 負荷電力に対する PV 出力の割合が 0.91 以上の場合となる。

Fig. 8, Fig.9のように, 晴天時の PV 出力の推定波形は, 力率の微視的変動によって誤差を生じているが，その変化 は, PV 出力の真值の前後で変動していると推測できる。し たがって，このような微視的変化による誤差を抑制するに は，提案手法(1による推定波形に正弦波形をフィッティン グする提案手法(2)適用が有効であると考えられる。

Table 2 より, 提案手法(2)の方が総誤差量は小さく，また 最大誤差点の誤差, 最大誤差率も大幅に小さくなっている ことが分かる。正弦波形でフィッティングした場合，变動 量に引きずられて提案手法(1で良好に推定できている部分 が真值から乘離してしまうことが予想されるが，誤差率が 最大の点の誤差は抑制することができ，総合的に精度の向 上になったものと考えられる。提案手法(2)適用に際して 許容できる誤差率を $5 \%$ とすると, 提案手法(2の適用範囲 は, 負荷電力に対する PV 出力の割合が 0.62 以上に向上し ている。このことから, PV の出力比率が小さいケースに おいて日射波形を先験情報として用いることの有効性を示 すことができた。

PV の出力比率が小さいケースに扔いてさらなる高精度 推定を目指すには，大きさの精度に関する定量的評価が必 要であり, 負荷力率変動量と推定誤差との関係を明らかに する分析が必要である。

〈7・3〉 正弦波フィッティングによる誤差抑制に関する考 察推定した波形に正弦波をフィッティングする目的は,
短周期の微細な力率変動により生じる誤差を抑制すること である。一方, 力率の変化様相の相違に基づく ICA 適用区 間の分割は, 長周期の大幅な力率変動により推定波形が近 似正弦波形から大きく逸脱するのを防ぐことを狙いとして いる。この観点から Fig. 8, Fig.9の Proposed(1)を見ると, Fig. 8 では近似正弦波形が良好に推定できている。Fig. 9 で は, 短周期の力率変動とそれに伴う無効電力変動の影響に より誤差が大きくなっているが, Fig. 8 と同様に近似正弦波 形は推定できている。この近似正弦波形に正弦波をフィッ ティングしたものが，Fig.9の Proposed(2)の波形になり， Fig. 9 の Proposed(1)よりも平均的に見て誤差が抑制されて いることが分かる。このことから，ICA 適用区間に占める 短周期の力率変動が生じている区間の割合が大きくなった としても, 推定波形には $P_{d g}$ の低周波成分の変化実態は反 映されていると推察される。この推定波形に正弦波フィッ ティングを行うことで, 短周期の力率変動による誤差を除 いた低周波成分の変化状態を近似する波形の推定は可能で あると考えられる。

\section{8. まとめ}

本論文では, 負荷電力と $\mathrm{PV}$ 出力曲線の先験情報を利用 してICAによる波形推定アルゴリズムを構築し, 両者を分 離・推定する手法を提案し, 数值シミュレーションによっ てその有効性を検証した。その結果, 本論文で用いた推定 対象では，日射波形をもうひとつの先験情報として用いた 提案手法の方が, 広範囲のパラメー夕变化に対して良好に 分離出来ることが分かった。力率の変動による誤差はICA 計算を行う上で無視出来ない要素であるのにもかかわらず, 現実の観測データではこれが一定值を維持していることは 極めて稀であることから, 力率変動のような不確定要素に 左右されることがない日射波形をフィットさせる手法が精 度の向上に繋がると考えられる。

今後の課題としては, 力率の変動が推定值に及ぼす影響 の定量的解明や負荷に対する PV 出力のピーク電力比が小 さい場合の対処法が挙げられる。また, PV が無効電力を 出力している場合の推定值への影響評価も必要である。

最後に数值シミュレーションでご協力頂いた，大阪府立 大学大学院 工学研究科松田真典 氏に感謝申し上げる。

\section{文献}

(1) H. Kobayashi: "Development Trend and Subjects of New Distribution Network Technology", IEEJ Trans. PE, Vol.124, No.4, pp.517-520 (2004-4) (in Japanese)

小林広武 :「新しい配電ネットワーク技術の開発動向と課題」, 電学 論 B, Vol.124, No.4, pp.517-520 (2004-4)

(2) T. Ishikawa: "Outline of Grid-interconnection Technologies of Distributed Generation Systems", IEEJ Trans. PE, Vol.126, No.10, pp.964-968 (200610) (in Japanese)

石川忠夫 : 「分散形電源の電力系統連系技術の最新動向」, 電学論 $\mathrm{B}$, Vol.126, No.10, pp.964-968 (2006-10)

(3) Y. Hayashi: "Trend and Future View of Voltage Control for Distribution Systems with Distributed Generators", IEEJ Trans. PE, Vol.129, No.4, pp.491494 (2009-4) (in Japanese)

林 泰弘:「分散型電源の導入拡大に対応した配電系統電圧制御の 
動向と展望」,電学論 B, Vol.129, No.4, pp.491-494 (2009-4)

(4) N. Watanabe, Y. Ogihara, Y. Kataoka, and N. Hiraiwa: "Estimation Method for Photovoltaic Generation Power Based on Section Switch Data", Proc. of 2009 Annual Conference of Power \& Energy Society, IEE Japan, No.138, pp.07-1-07-2, (2009) (in Japanese)

渡邊直人・荻原義典·片岡泰宏·平岩直哉：「区間開閉器情報を用い た太陽光発電量把握手法の一検討」, 平成 21 年電気学会電力・エネ ルギー部門大会, No.138, pp.07-1-07-2 (2009)

(5) Y. Ogihara, N. Hiraiwa, T. Aihara, Y. Kobayashi, and M. Watanabe: "On the Evaluation of a Section Switch Data Based Method for Distributed Generator Output Estimation", Proc. of 2009 Annual Conference of Power \& Energy Society, IEE Japan, No.219, pp.24-3-24-4 (2009) (in Japanese) 荻原義典・平岩直哉・相原孝志・小林康弘・渡辺雅浩：「区間開開器 情報を用いた分散型電源発電量把握手法の評価」, 平成 21 年電気学 会電力・エネルギー部門大会, No.219, pp.24-3-24-4 (2009)

(6) K. Matsuda, K. Horikoshi, Y. Nakano, T. Onoda, M. Asari, and N. Ito: "Proposal of a Method to Estimate the Operating Status of the Distributed Generators", IEEJ Trans. PE, Vol.130, No.6, pp.593-602 (2010-6) (in Japanese) 松田勝弘・堀越和宏・中野幸夫 ·小野田崇・浅利真宏 - 伊藤憲彦： 「分散形電源の運転状況推定手法の提案」, 電学論 B, Vol.130, No.6, pp.593-602 (2010-6)

(7) S. Naka, S. Tohne, T. Genji, T. Yura, Y. Fukuyama, and S. Takayama: "Distribution State Estimation Considering Practical Equipment in Distribution Systems", T. IEE Japan, Vol.120-B, No.12, pp.1566-1572 (2000-12) (in Japanese)

仲 成規・藤根 栄·元治 崇 · 由良俊樹 · 福山良和 · 高山信一： 「実系統機器の特性を考慮した配電系統状態推定方式の検討」, 電学 論 B, Vol.120, No.12, pp.1566-1572 (2000-12)

(8) K. Tanomura, Y. Ogita, Y. Kaneshige, J. Ishii, and J. Arai: "A Voltage and Power Flow State Calculation Technique of Distribution System using Measurement Values", IEEJ Trans. PE, Vol.125, No.10, pp.948-956 (2005-10) (in Japanese)

田能村顕一・荻田能弘 - 兼重由美子 - 石井淳之 ·荒井純一：「計測 情報を利用した配電系統の電圧・潮流分布状態計算手法」, 電学論 B, Vol.125, No.10, pp.948-956 (2005-10)

(9) T. Mitsuyama, N. Hiraiwa, K. Ogawa, M. Watanabe, M. Kushida, and H. Shimamura: "Development of State Estimation Method for Distribution System using Measurement Data", Proc. of 2008 Annual Conference of Power \& Energy Society, IEE Japan, No.231, pp.24-23-24-24 (2008) (in Japanese)

満山照樹・平岩直哉・小川謙治・渡辺雅浩・櫛田 䢐・島村秀彦：「七 ンサ内蔵開閉器の計測データを用いた配電系統状態推定手法の検討」, 平成 20 年電気学会電力・エネルギー部門大会, No.231, pp.24-23-24-22 (2008)

(10) A. Hyvarinen, J. Karhunen, and E. Oja（根本 幾・川勝真喜 訳)：詳解 独立成分分析一信号解析の新しい世界, 東京電機大学出版局 (2005)

(11) M. Yanagida and A. Ishigame: "Estimating Technique for the Output of Distributed Generation Using Independent Component Analysis", IEEJ Trans. $P E$, Vol.127, No.1, pp.217-223 (2007-1) (in Japanese)
柳田将臣・石亀篤司：「独立成分分析による分散型電源出力の推定」, 電学論 B, Vol.127, No.1, pp.217-223 (2007-1)

(12) Y. Kamii and K. Chikamori: "A Calculation Method of Solar Radiation Incident upon Slopes", Kohchi University Technical Report, Vol.47, Natural Science (1998)

紙井泰典・近森邦英：「斜面日射量の計算方法について」, 高知大学学 術研究報告, Vol.47, 自然科学 (1998)

山 田 貴 義 （学生員） 1983 年生。 2008 年 3 月大阪府立大学

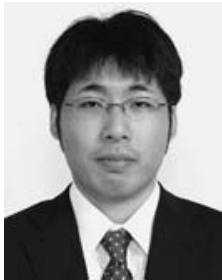
工学部電気電子システム工学科卒業。同年 4 月大 阪府立大学大学院工学研究科電気・情報系専攻博 士前期課程入学，現在は関西電力（株）勤務。在 学中は，主として配電系統の状態推定に関する研 究に従事。

石 亀 篤 司（上級会員） 1963 年生。1989 年 3 月大阪府立大

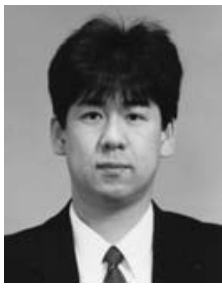
学大学院工学研究科電気工学専攻博士前期課程修 了。同年 4 月同大学工学部助手, 講師, 准教授 を経て，2010 年 4 月同大学大学院工学研究科教 授，現在に至る。1995 年 8 月 1996 年 7 月米国 コーネル大学客員研究員。電力系統の解析・制御 に関する研究に従事。博士 (工学)。電気設備学 会，IEEE 会員。

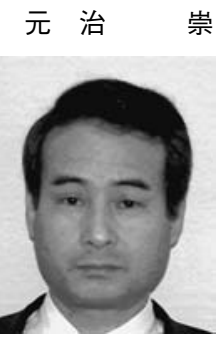

(正員) 1951 年生。 1975 年 3 月岡山大学大学院 工学研究科修了。同年 4 月関西電力 (株) 入社。 1985 年から同社研究開発室電力技術研究所勤務。 主として配電線雷害対策・配電自動化·分散型電 源連系に関する研究に従事。現在，同研究所電力 基盤技術研究室主席研究員。2006 年電気学会論 文賞受賞。 